\title{
EFFECT OF HARVESTING TIME ON SEED PHYSIOLOGICAL QUALITY, CHEMICAL COMPOSITION AND STORABILITY OF SOYBEANS ${ }^{1}$
}

\author{
J. MARCOS-FILHO ${ }^{2}$; H.M.C.P. CHAMMA; J.R. R. CASAGRANDE; E.A. MARCOS \\ Departamento de Agricultura - ESALQ/USP, C.P. 9, CEP: 13418-900 - Piracicaba,SP \\ M.A.B. REGITANO-d'ARCE \\ Departamento de Ciencia e Tecnologia Agroindustrial - ESALQUSP, C.P. 9, CEP: 13418-900 - Piracicaba,SP
}

\begin{abstract}
Soybeans IAC-8 were harvested in the growth stages R7 and R8 commercial harvesting time and at two other subsequent times to compare their physiological and technological characteristics. Seeds were stored at two moisture levels, $12 \%$ and $15 \%$, for 6 months. Germination and vigor (acelerated aging, electrical conductivity), oil and free fatty acids, peroxide and iodine values were evaluated periodically. As expected, the time of harvesting and seed moisture content affected seed performance, while oil content did not correlate to physiological quality as did acidity, peroxide value and iodine number.
\end{abstract}

Key Words: Glycine max, seeds, maturation, storage, germination vigor.

\section{RELAÇÕES ENTRE MOMENTO DE COLHEITA, COMPOSIÇÃo QứMICA E POTENCIAL DE ARMAZENAMENTO DE SEMENTES DE SOJA.}

RESUMO: Um campo de produção de soja IAC-8 foi colhido nos estádios R7 e R8 "pontos de colheita comercial" e em duas épocas subsequentes; as sementes foram estudadas sob os pontos de vista físiologico e tecnologico, logo ap6s as colheitas e durante 0 armazenamento de 6 meses (graus de umidade inicial de 12\% e 15\%). 0 comportámento das sementes foi avaliado através de testes de germinação, vigor (envelhecimento acelerado, condutividade elétrica), teores de óleo e de ácidos graxos livres, indices de peróxidos e de iodo. 0 momento de colheita $\mathbf{o}$ grau de umidade afetaram o desempenho das sementes mas o teor de óleo não se relacionou à qualidade fisiologica, o que ocorreu com os índices de per6xidos e de iodo.

Descritores: Glycine max, sementes, maturação, armazenamento, germinação, vigor.

\section{INTRODUCTION}

The harvesting time is one of the critical steps in soybean seeds production. Unavoidable delays or those resulting from careless farmer's attention cause the exposition of the seeds to unfavorable environmental conditions and the acceleration of the deterioration process. Therefore, it is necessary to harvest at a time as close as possible to the physiological maturity, that is, after the stabilization of dry matter translocation to the seeds, when they reach the maximum germination and vigor potential (JACINTHO e CARVALHO, 1974; MARCOS-FILHO et al., 1981; MARCOSFILHO et al., 1975). Soybeans should be harvested as soon as seed moisture comes to a level that allows mechanization.
According to FRANCA-NETO \& HENNING (1984) soybean seed deterioration in the field involves physical, physiological or microorganism caused alterations. Field deterioration is intensified by high temperatures or by moisture oscillations, when respiration, lipid and protein degradation and microorganisms development increase and enzymatic activity is reduced and consequently, germination and vigor reductions are verified.

On the other hand, seed conservation potential during storage is directly related to environmental conditions (mainly temperature and relative humidity) as pointed out by other researchers. However seed initial quality determined by its pre- and post-harvest history is fundamental. FERGUSON et al. (1990 a,b)

\footnotetext{
${ }^{1}$ Presented at the XXIII International Seed Testing Congress. Buenos Aires, Argentina, 02-04 November, 1992.

2 Bolsista do CNPq.
} 
verified the occurrence of mitochondrial function abnormalities and hence, respiratory rate decline, during the initial stages of soybean seeds deterioration. These alterations may be associated to lipid peroxidation, even before a pronounced reduction in germination and vigor are observed.

Consequently, it is important that soybean seeds are stored at moderate temperatures and relative humidity below to $70 \%$ (EGLI et al., 1979). According to ROBERTSON et al. (1973) field-damaged soybean seeds stored at high moisture levels deteriorated even faster. Their oil presented high free fatty acid content, unpleasant flavor and high refining losses. The higher the unsaturation degree of the fatty acids, the faster their concentrations were reduced.

A high correlation betweeen free fatty acid content and iron content was found in injured soybean seeds leading to poor quality refined oils (EVANS et al., 1974; LIST et al., 1977). Oil acidity increase during storage was proportional to initial free fatty acid content (YAO et al., 1983). The closer to the ideal seed moisture content, the less triglyceride hydrolysis ocurred in soybean during storage. Seeds stored at $13 \%$ moisture level prevented peroxide formation during 50 days (FRANKEL et al., 1987).

Based on these facts, this work was conducted aiming mainly to study the relationship between the time of harvesting and soybean storability, seeking to characterize the interaction between physiological and chemical manifestations of the deterioration process.

\section{MATERIAL AND METHODS}

Soybean seeds, cultivar IAC-8, were grown by a seed producer at Malabar farm in Itatiba, SP, Brazil. Part of the field area was delimited, using an experimental randomized block design, with six replicates. The seeds were sown on December 4, 1989.

Seeds were harvested at five different times, which were R7 and R8 stages (FEHR \& CAVINESS, 1980), commercial harvesting time (H) and at 13 and 28 days after this point (C1 and C2, respectively).

Following each harvest, the moisture content and dry matter weight (oven method, $105^{\circ} \mathrm{C}$ for 24 hours) were determined for samples of 100 seeds per replicate. When seeds reached $15 \%$ moisture, after plant drying and hand treshing, one half of the seed samples was stored in chamber $A_{1}$ while the other was kept drying till $12 \%$ moisture, and then stored under normal environmental conditions (A2). These seed moisture contents were checked at the beginning, at 3 and 6 months of storage. The germination, accelerated ageing and electrical conductivity tests were performed according to the INTERNATIONAL SEED TESTING ASSOCIATION (1976) and Seed Vigor Testing Handbook (ASSOCIATION OF OFFICIAL SEED ANALYSTS, 1983), respectively.

Oil content was determined according to the Norme Grassi e Derivati (NGD A-4) (1976). The oil quality was evaluated according to the free fatty acid content (NGD C-10), peroxide value (NGD C-35), iodine number (NGD C-32) and iron and copper contents (AOCS $\mathrm{Ca}$ 18-79), with adaptations. The oil for these analysis was obtained from ground seeds with hexane as the solvent, in glass Soxhlet extractors. The solvent was recovered in rotary vaccum evaporator at a maximum temperature of $60^{\circ} \mathrm{C}$.

\section{RESULTS AND DISCUSSION}

Seed moisture (TABLE 1) was high at R7 and R8 harvests. This point has been characterized by TeKRONY et al. (1979) as the physiological maturity stage, when the seeds would have accumulated maximum dry matter. Although these data have not been statistically analysed, the moisture content of the seeds has decreased from R7 to R8 and, in the subsequent harvest times, the observed variations may reflect the different hygroscopic equilibrium points attained with the air relative humidity. After R7, the wettest seeds were harvested at $\mathrm{H}$ (commercial harvest point).

The dry matter weight data were statistically similar. The numerical variations among the average values may reflect the considerations of TeKRONY et al. (1979). They are precise enough due to the serious difficulties in controlling adequately their causes of variation and in determining small variations in weight.

The germination evaluation performed after each harvest showed that the R8 and $\mathrm{H}$ seeds are significantly superior to the others. The results presented in TABLE 2 indicate that maximum germination did not coincide with $\mathbf{R 8}$ as expected if there had been coincidence of this parameter with the point of maximum seed dry weight.

TABLE 2 also shows the negative effects of delaying harvest ( $\mathrm{C1}$ and $\mathrm{C2}$ ), usually presented in the literature. 
TABLE 1. Dry matter weight ( $g / 100$ seeds) and moisture content (\%) of seeds harvested at different times.

\begin{tabular}{lcc}
\hline Harvest & $\begin{array}{c}\text { Dry matter } \\
\text { weight (g/100 seeds) }\end{array}$ & $\begin{array}{c}\text { Moisture } \\
\text { content (\%) }\end{array}$ \\
\hline R7 & $15,34 \mathrm{~A}\left(^{*}\right)$ & 60,9 \\
R8 & $16,30 \mathrm{~A}$ & 17,5 \\
H & $15,90 \mathrm{~A}$ & 19,5 \\
C1 & $16,33 \mathrm{~A}$ & 16,0 \\
C2 & $16,07 \mathrm{~A}$ & 16,6 \\
\hline
\end{tabular}

(*) Means within a column followed by the same letter are not significantly different at $P=0,05$, according to Tukeytest.

TABLE 2. Germination (\%) of soybean seeds during storage in chamber $\left(A_{1}\right)$ and under normal environmental conditions $\left(A_{2}\right)$.

\begin{tabular}{|c|c|c|c|c|}
\hline \multirow{2}{*}{ Harvest } & \multicolumn{2}{|c|}{$A_{1}$} & \multicolumn{2}{|r|}{$A_{2}$} \\
\hline & 0 & 3 months & 0 & 6 months \\
\hline R7 & $76 \mathrm{Ba}(*)$ & $10 \mathrm{Ab}$ & $76 \mathrm{Ba}$ & $72 \mathrm{Aa}$ \\
\hline R8 & $98 \mathrm{Aa}$ & $3 \mathrm{Bb}$ & $98 \mathrm{Aa}$ & $77 \mathrm{Ab}$ \\
\hline H & $94 \mathrm{Aa}$ & $2 \mathrm{BCb}$ & $94 \mathrm{Aa}$ & $75 \mathrm{Ab}$ \\
\hline C1 & $84 \mathrm{Ba}$ & $1 \mathrm{Cb}$ & $84 \mathrm{Ba}$ & $72 \mathrm{Ab}$ \\
\hline C2 & $66 \mathrm{Ca}$ & $0 \mathrm{Cb}$ & $66 \mathrm{Ca}$ & $57 \mathrm{Bb}$ \\
\hline
\end{tabular}

(*) Means within a column followed by the same capital letter are not significantly different at $P=$ 0,05 according to Tukey test. Means within a row followed by the same small letter are not significantly different at $\mathbf{P}=0,05$, according to Tukey test.

The seeds stored in chamber $A_{1}$ had very poor germination performances after 3 months of storage. Several authors among them, EGLI $e t$ al. (1979) and MARCOS-FILHO et al. (1985) have referred to the difficulty in conserving soybean seeds at moisture levels over $12 \%$.

On the other hand, there has been a significant decrease in germination of the seeds stored in normal environmental conditions $\left(A_{2}\right)$, with average moisture content $12 \%$. The lowest quality seeds were the ones from $\mathrm{C} 2$, however the others did not reach compatible levels for commercialization, either.
TABLE 3 shows that the artificial ageing has followed the germination in a general sense. Statistical analysis of the data showed that this analysis is more sensitive than the previous one, furnishing aditional information like the superiority of the R8 seeds with respect to $H$ seeds and the advantage of executing harvest in anticipation (R7) and, the serious implications when it is delayed ( $\mathrm{Cl}$ and $\mathrm{C2}$ ). It has been observed again that the dry matter accumulation process (final step) did not coincide with the maximum physiological quality.

Nevertheless, the artificial ageing is considered efficient to detect differences in the storability of seed lots. This has been confirmed here. The R8 and $\mathrm{H}$ seeds had higher vigor marks than the others and even after 6 months of storage, higher germination values.

Statistical analysis of the electrical conductivity data has demonstrated that the interaction harvest time $\mathrm{x}$ storage periods was significative. In the two testing times, R7 seeds were considered the most vigorous. After six months of storage, R8 seeds could also be distinguished from the others (TABLE 3).

The electrical conductivity of the exsudates evaluates indirectly the vigor of the seeds, expressed through the integrity of the cellular membrane system. Theoretically, this organization must be completed in a time near maximum dry matter accumulation, during the seed maturation.

The results from this work are consistent with this observation. However, one shall expect the first deterioration event to be the loss of membrane integrity and, further alterations like the lesser resistance to environmental conditions (represented in this work by the aging test), reduction of speed and percentage germination to occur during the evolution of the process. These results reinforce the idea of the need to conclude on vigor levels, based on a set of results of different tests.

The least oil content was found in R8 seeds whereas the R7, H, C1 and C2 oil content did not differ statistically from one another (TABLE 4).

The oil from $\mathrm{R} 8$ and $\mathrm{H}$ seeds were the least acid. The others had already gone through some severe hydrolysis which had already been observed by FRANCA NETO \& HENNING (1984). 
TABLE 3. Vigor: mean values obtained in accelerated aging and electrical conductivity tests conducted on seeds harvested at different times and stored for six months under normal environmental conditions (A2).

\begin{tabular}{cccccc}
\hline \multirow{2}{*}{ Harvest } & \multicolumn{3}{c}{ Accelerated Aging (\%) } & \multicolumn{2}{c}{ Conductivity (umhos/g/cm) } \\
\cline { 2 - 6 } & 0 & 6 & Mean & 0 & 6 \\
\hline R7 & 70 & 62 & $66 \mathrm{C}^{(9)}$ & $43,4 \mathrm{Aa}$ & $34,7 \mathrm{Ab}$ \\
R8 & 94 & 89 & $92 \mathrm{~A}$ & $60,0 \mathrm{Ba}$ & $49,7 \mathrm{Bb}$ \\
H & 87 & 76 & $82 \mathrm{~B}$ & $63,5 \mathrm{Ba}$ & $57,0 \mathrm{Cb}$ \\
C1 & 54 & 49 & $52 \mathrm{D}$ & $64,7 \mathrm{Ba}$ & $55,8 \mathrm{Cb}$ \\
C2 & 36 & 28 & $32 \mathrm{E}$ & $68,1 \mathrm{Ba}$ & $67,1 \mathrm{Da}$ \\
\hline Mean & $71 \mathrm{a}$ & $62 \mathrm{~b}$ & - & - & - \\
\hline \hline
\end{tabular}

(*) Means within a column followed by the same capital letter are not significantly different at $\mathrm{P}=0,05$ according to Tukey test. Means within a row followed by the same small letter are not significantly different at $\mathrm{P}=0,05$, according to Tukey test.

TABLE 4. Oil content (\%) of seeds harvested at different times.

\begin{tabular}{lccccc}
\hline Harvest & R7 & R8 & H & C1 & C2 \\
\hline Mean & $18,6 a b(*)$ & $17,3 b$ & $19,8 a$ & $19.3 a$ & $20,2 a$ \\
\hline
\end{tabular}

(*) Means within a row followed by the same small letter are not significantly different at $P=0,05$, according to Tukey test.

After 3 month storage, seeds with $15 \%$ moisture were slightly richer in free fatty acids than the oils from the seeds stored with $12 \%$ moisture. The latter showed a tendency to decrease in acidity within 6 months of storage.

Confirming the free fatty acid data, R8 and $\mathrm{H}$ seed oils were the best in quality regarding peroxide values. Statistical analysis reveals that only $\mathrm{C} 1$ and $\mathrm{C} 2$ seed oils had their peroxide values decreased with storage, indicating a faster process of deterioration.

Regarding iodine values, again R8 and $H$ seed oils were the best, with higher degree of unsaturation, which is associated with a larger number of unsaturated fatty acids whose double links have not initiated the peroxidation process. During storage, only R8 and $\mathrm{H}$ seed oils iodine values decreased, indicating that due to their higher initial iodine values the fatty acid isomerization, a part of the peroxidation process, started during the storage. For the others the process had already been on activity since the harvest time.

Iron and copper contents found in the oils were inferior to $0,5 \mathrm{ppm}$ and $0,02 \mathrm{ppm}$, respectively. Due to these low concentrations its influence on the process of peroxidation, and hence deterioration, can be discarted.

The results here obtained indicate that the harvest time affects physiological and technological quality of the seeds. The moisture level of the seeds kept during storage influences significantly seed behavior. Storage of wetter materials renders faster deterioration with harmful variations in the characteristics of the oil during storage.

It should be pointed out that it was possible to associate physiological and chemical alterations in the seeds. However, it was observed that the oil content could not be directly associated to seed physiological quality. When it showed to be superior, the seeds presented the lowest oil content (R8).

It was evident that the characteristics or components of the oil must be considered a priority in this kind researches and also in date searching programs for the quality control. It should be emphasized the consistent relationship between oil acidity, peroxide, iodine indexes and seed germination and vigor. 
TABLE 5. Free fatty acid content (\%) of seed oils from different harvest times stored in chamber (A1) and under normal environmental conditions (A2).

\begin{tabular}{|c|c|c|c|c|c|c|c|}
\hline \multirow{2}{*}{ Harvests } & \multicolumn{2}{|c|}{ Al (months) } & \multirow{2}{*}{ Mean } & \multicolumn{3}{|c|}{ A2 (months) } & \multirow{2}{*}{ Mean } \\
\hline & 0 & 3 & & 0 & 3 & 6 & \\
\hline R7 & 1.16 & 1.92 & $1.52 \mathrm{~A}^{(\mathrm{y})}$ & 1.16 & 1.80 & 1.72 & $1.54 \mathrm{~A}$ \\
\hline R9 & 0.62 & 1.50 & $1.02 \mathrm{~B}$ & 0.62 & 1.29 & 1.25 & $1.03 \mathrm{BC}$ \\
\hline $\mathbf{H}$ & 0.62 & 1.72 & $1.10 \mathrm{~B}$ & 0.62 & 1.33 & 1.20 & $0.97 \mathrm{C}$ \\
\hline $\mathrm{C} 1$ & 1.03 & 1.65 & $1.32 \mathrm{AB}$ & 1.03 & 1.28 & 1.20 & $1.18 \mathrm{BC}$ \\
\hline $\mathrm{C} 2$ & 0.94 & 1.57 & $1.24 \mathrm{AB}$ & 0.94 & 1.51 & 1.31 & $1.24 \mathrm{AB}$ \\
\hline Mean & $0.86 b$ & $1.67 \mathrm{a}$ & & $0.86 b$ & $1.39 \mathrm{a}$ & $1.34 \mathrm{a}$ & \\
\hline
\end{tabular}

${ }^{*}$ ) Means within a column followed by the same capital letter are not significantly different at $P=0,05$ according to Tukey test. Means within a row followed by the same small letter are not significantly different at $P=0,05$, according to Tukey test.

TABLE 6. Peroxide values (meq $\mathrm{O}_{2} / 1000 \mathrm{~g}$ oil) of seed oils from different harvest times stored in chamber (A1) and under normal environmental conditions (A2).

\begin{tabular}{cccccc}
\hline \multirow{2}{*}{ Harvests } & \multicolumn{2}{c}{$\mathrm{Al}$ (months) } & \multicolumn{3}{c}{$\mathrm{A} 2$ (months) } \\
\cline { 2 - 6 } & \multicolumn{1}{c}{0} & 3 & 0 & 3 & 6 \\
\hline $\mathrm{R} 7$ & $2.14 \mathrm{ABa}^{(9)}$ & $1.30 \mathrm{Aa}$ & $2.14 \mathrm{ABa}$ & $2.30 \mathrm{Aa}$ & $1.03 \mathrm{Aa}$ \\
$\mathrm{R} 9$ & $0.29 \mathrm{Ba}$ & $0.69 \mathrm{Aa}$ & $0.19 \mathrm{C}$ & $0.37 \mathrm{Aa}$ & $1.30 \mathrm{Aa}$ \\
$\mathrm{H}$ & $1.21 \mathrm{ABa}$ & $0.79 \mathrm{Aa}$ & $1.21 \mathrm{BCa}$ & $1.13 \mathrm{ABa}$ & $1.61 \mathrm{Aa}$ \\
$\mathrm{C} 1$ & $2.43 \mathrm{Aa}$ & $0.65 \mathrm{Ab}$ & $2.43 \mathrm{ABa}$ & $1.86 \mathrm{Aa}$ & $1.03 \mathrm{Aa}$ \\
$\mathrm{C} 2$ & $4.31 \mathrm{Aa}$ & $0.18 \mathrm{Ab}$ & $4.34 \mathrm{Aa}$ & $0.83 \mathrm{ABb}$ & $0.96 \mathrm{Ab}$ \\
\hline \hline
\end{tabular}

(") Means within a column followed by the same capital letter are not significantly different at $P=0,05$ according to Tukey test. Means within a row followed by the same small letter are not significantly different at $\mathrm{P}=0,05$, according to Tukey test.

Futhermore, data suggest speculations regarding the confidence on the information obtained from the electrical conductivity test. This method can be considered as one of the most sensitive and efficient to evaluate seed vigor. However it originated conflicting data with the other tests, more evidently when peroxide values (smaller values in $\mathrm{R} 8$ and $\mathrm{H}$ ) are taken into consideration. It is known that phospholipids are components of cellular and organellae membrane and, consequently, lipid peroxidation and free radical formation consist characteristic alterations during deterioration. It is believed that non detected problems have interferred in the conductivity test results.

\section{ACKNOWLEDGEMENT}

To Fundação de Amparo à Pesquisa do Estado de São Paulo (FAPESP) and Conselho Nacional de Desenvolvimento Científico e Tecnológico $(\mathrm{CNPq})$ for financial support. 
TABLE 7. lodine number ( $\mathrm{mg}$ lodine $/ 100 \mathrm{~g}$ oil) of seed oils from different harvest times stored in chamber (A1) and under normal environmental conditions (A2).

\begin{tabular}{ccccccc}
\hline \multirow{2}{*}{ Harvests } & \multicolumn{3}{c}{ Al (months) } & \multicolumn{3}{c}{ A2 (months) } \\
\cline { 2 - 7 } & 0 & 3 & Mean & 0 & 3 & 6 \\
\hline R7 & 124.08 & 117.94 & $121.00 \mathrm{~B}^{(9)}$ & $124.08 \mathrm{Ba}$ & $121.92 \mathrm{Aa}$ & $126.63 \mathrm{Aa}$ \\
R9 & 131.99 & 121.02 & $126.50 \mathrm{~A}$ & $131.99 \mathrm{Aa}$ & $119.89 \mathrm{Ab}$ & $124.10 \mathrm{Ab}$ \\
$\mathrm{H}$ & 133.20 & 122.35 & $127.78 \mathrm{~A}$ & $133.20 \mathrm{Aa}$ & $122.39 \mathrm{Ab}$ & $127.18 \mathrm{Ab}$ \\
$\mathrm{C} 1$ & 130.67 & 123.30 & $126.98 \mathrm{~A}$ & $130.67 \mathrm{ABa}$ & $125.97 \mathrm{Aa}$ & $126.14 \mathrm{Aa}$ \\
$\mathrm{C} 2$ & 126.36 & 121.90 & $124.13 \mathrm{AB}$ & $126.36 \mathrm{ABa}$ & $125.80 \mathrm{Aa}$ & $126.36 \mathrm{Aa}$ \\
\hline Mean & $129.26 \mathrm{a}$ & $121.30 \mathrm{~b}$ & & - & - & - \\
\hline \hline
\end{tabular}

(") Means within a column followed by the same capital letter are not significantly different at $\mathrm{P}=0,05$ according to Tukey test. Means within a row followed by the same small letter are not significantly different at $P=0,05$, according to Tukey test.

\section{REFERENCES}

AMERICAN OIL CHEMISTS' SOCIETY. Official and tentative methods. 3 ed. Champaign: AOCS, 1983.

ASSOCIATION OF OFFICIAL SEED ANALYSTS. Seed vigor testing handbook. Springfield, 1983. 1v.

EGLI, D.B; WHITE, D.M.; TeKRONY, D.M. Relationship between seed vigor and the storability of soybean seed. Journal of Seed Technology, Champaign, v.3, p.1-11, 1979.

EVANS, C.D: LIST, G.R.; BEAL, R.E ; BLACK, L.T. Iron and phosphorous contents of soybean oil from normal and dawaged beans. Journal of the American Oil Chemists Society, New York, v.51, p.444-448, 1974.

FEHR, W.E.; CAVINESS, C.E. Stages of soybean development. Special Report 80. Cooperative Extension Service, lowa State University. 11 p, 1980.

FERGUSON, J.M.; TeKRONY, D.M.; EGLI, D.B. Changes during early soybean seed and axes deterioration: I. Seed quality and mitochondrial respiration. Crop Science, Utah, v.30, p.175-179, 1990a.

FERGUSON, J.M; TeKRONY, D.M.; EGLI D.B. Changes during early soybean seed and axes deterioration: Il. Lipids. Crop Science, Utah, v.30, p.179-182, $1990 \mathrm{~b}$.
FRANÇA-NETO, J.B; HENNING, A.A. Qualidade fisiológica e sanitária de sementes de soja. Londrina. EMBRAPA/CNPSoja, 39p, 1984. (Circular Técnica, 9).

FRANKEL, E.N.; NASH, A.M.; SNUDER, J.M. A methodology study to evaluate quality of soybeans stored at different moisture levels. Journal of the American Oil Chemists'Society, New York, v.64, p.987-992, 1987.

INTERNATIONAL SEED TESTING ASSOCIATION. International Rules for Seed Testing. Annexes 1976. Seed Science and Technology, Oklahoma, v.4, p.51$177,1976$.

JACINTHO, J.B.C.; CARVALHO, N.M. Maturação de sementes de soja. Cientifica, Jaboticabal, v.1, p.81-88, 1974 .

R.E.; KWOLEK, W.F.; BLACK, L.T.; MOULTON, K.J. Quality of oil from damaged soybeans. Journal of the American Oil Chemists' Society, New York, v.54, p.8-14, 1977.

MARCOS-FILHO, J.; AMORIM, H.V.; SILVAROLLA, M.B.; PESCARIN H.M. Relações entre germinação, vigor e permeabilidade das membranas celulares durante a maturação de sementes de soja. In: SEMINÁRIO NACIONAL DE PESQUISA DE SOJA. Brasilia, 1981. Resumos... Brasília: EMBRAPA/CNPsoja, 1981, v.2, p.676-688. 
MARCOS-FILHO, J.; CARVALHO, R.V.; CÍCERO, S.M.; DEMÉTRIO, C.G.B. Qualidade fisiológica e comportamento de sementes de soja no armazenamento e no campo. Anais da Escola Superior de Agricultura "Luiz de Queiroz", Piracicaba, v.42, p.195-249, 1985.

ROBERTSON, J.A.; MORRISON, III, W.H.; BURDICK, D. Chemical evaluation of oil from fieldand storage- damaged soybeans. Journal of the American Oil Chemists' Society, New York, v.50, p.443-445, 1973.
TeKRONY, D.M.; EGLI, D.B.; BALLES. J.; PFEIFFER, T.; FELLOWS, J.R. Physiological maturity of soybean. Agronomy Journal, Madison, v.71, p.771-775, 1979.

YAO, J.J.; WEI, L.S.; STEINBERG, M.P. Effect of maturity on chemical composition and storage stability of soybeans. Journal of the American Oil Chemists' Society, New York, v.60, p.1245-1249, 1983.

Enviado para publicação em 13.12.93

Aceito para publicação em 24.01.94 